\title{
Design and manufacture of protective elements to prevent accidents in the agricultural machinery of Ecuador, two cases of study in automotive elements.
}

Design and manufacture of protective elements to prevent accidents in the agricultural machinery of Ecuador, two cases of study in automotive elements.

Edison Marcelo Castillo Cárdenas. ${ }^{1}$, Víctor David Bravo Morocho. ${ }^{2}$, Edison Patricio Abarca Pérez. ${ }^{3}$, Edgar Fabián Sánchez Carrión. ${ }^{4} \&$ Paúl Alejandro Montúfar Paz. ${ }^{5}$

Recibido: 20-03-2017 / Revisado: 07-05-2017 Aceptado: 08-06-2018/ Publicado: 01-07-2018

Abstract.

DOI: https://doi.org/10.33262/cienciadigital.v2i3.146

The present work deals with the exposure, analysis and source of risks the two common work accidents and of greater impact in the Agricultural Mechanization Centers, internal part of MAG (Ministry of Agriculture and Livestock of Ecuador) whose main machine after the tractors and the which it is the object of study in the present treaty is the YTO DF 151 model walking tractor: a) blows and bruises due to the ignition system, b) trapping and bruises due to the blades of the tillage element (rotavator). The most viable solutions are designed, manufactured, implemented and validated from the technological and economic point of view, the solutions were proven in the field and they are effective, however there are problems due to the implementation of the ignition system that leads to a new mass center of the tiller and there are maneuverability problems.

Keywords: Walking Tractor, Incidence Index, Accidents, Blades, Ignition Sytem.

\section{Resumen.}

El presente trabajo aborda la exposición, análisis y fuente de riesgos de los dos accidentes laborales comunes y de mayor impacto en los Centros de Mecanización

\footnotetext{
${ }^{1}$ Escuela Superior Politécnica de Chimborazo, Chimborazo, Ecuador, edison.castillo@espoch.edu.ec

${ }^{2}$ Escuela Superior Politécnica de Chimborazo, Chimborazo, Ecuador, victor.bravo@espoch.edu.ec

${ }^{3}$ Escuela Superior Politécnica de Chimborazo, Chimborazo, Ecuador, edison.abarca@espoch.edu.ec

${ }^{4}$ Escuela Superior Politécnica de Chimborazo, Chimborazo, Ecuador, esanchez_c@espoch.edu.ec

${ }^{5}$ Escuela Superior Politécnica de Chimborazo, Chimborazo, Ecuador, esanchez_c@espoch.edu.ec
} 
Agrícola, parte interna del MAG (Ministerio de Agricultura y Ganadería de Ecuador) cuya máquina principal después de los tractores y la cual El objeto del estudio en el presente tratado es el tractor a pie modelo 15 de YTO DF: a) golpes y hematomas debidos al sistema de encendido, b) atrapamiento y hematomas debido a las cuchillas del elemento de labranza (rotavator). Las soluciones más viables se diseñan, fabrican, implementan y validan desde el punto de vista tecnológico y económico, las soluciones fueron probadas en el campo y son efectivas, sin embargo, existen problemas debido a la implementación del sistema de ignición que conduce a una nueva centro de masa del timón y hay problemas de maniobrabilidad.

Palabras Claves: Tractor para Caminar, Índice de Incidencia, Accidentes, Cuchillas, Sistema de Encendido.

\section{Introducción .}

The study is done in the regional MAG (Ministry of Agriculture and Livestock of Ecuador) in Chimborazo, it is not necessary to indicate that this province is among the largest production of agriculture in Ecuador, the work structure of this ministry prioritizes in the direct conjuncture between farmers with the MAG through the technicians (professionals within agronomy and animal husbandry), this situation is achieved in the so-called "Agricultural Mechanization Centers" which are places attached to the aforementioned ministry that offer services of provision of agricultural machinery at the level of tractors and tractors, in the case of tractors is also provided with the respective tools, the machining centers benefit approximately 2000 farmers on average. [1].

Among the main objectives of the mechanization centers is to provide technical support with qualified machinery and machinists that are self-sustaining with the resources that enter the center. [2].

Among the main problems faced by a farmer who has the technical support of a machining center is the low reliability of the elements that is used both in the tools where there is a premature deterioration in the tools, this among the tractors.

There are a variety of problems among the power tillers, which generates a series of disadvantages when using them, among the main conflicts with the functionality is the ignition, the lack of ergonomic standards for the design of handles, operator seat, lack of protection elements that isolate the farmer from the rotavator, premature deterioration of the rotator blades, etc. In general, several general contents are indicated in an introduction, which it is necessary to expose for a better understanding of what follows. Among them we can outline schematically the background of the research, starting point or approach with which the problem is addressed, general and specific objectives of the work done, basic conceptualizations, personal observations. 
This study is important because its mission is after the analysis of this document to lower the rate of accidents at the agricultural machining centers belonging to the MAG of Ecuador by the use of tractors and mainly of power tillers, through design, construction, assembly and implementation of mechanical elements that prevent work accidents; the problem to which it is intended to attack is one of the factors that prevent farmers from working with relative confidence with the agricultural machinery that exists in the mechanization centers, since they state that they are more dangerous than traditional methods of tillage such as tillage of blood (yunta of cattle, horses, among others) and do not work with the machinery due to the fear that exists among the comuneros to have accidents during work.

In general, several general contents are indicated in an introduction, which it is necessary to expose for a better understanding of what follows. Among them we can outline schematically the background of the research, starting point or approach with which the problem is addressed, general and specific objectives of the work done, basic conceptualizations, and personal observations.

This study is important because its mission is after the analysis of this document to lower the rate of accidents at the agricultural machining centers belonging to the MAG of Ecuador by the use of tractors and mainly of power tillers, through design, construction, assembly and implementation of mechanical elements that prevent work accidents; the problem to which it is intended to attack is one of the factors that prevent farmers from working with relative confidence with the agricultural machinery that exists in the mechanization centers, since they state that they are more dangerous than traditional methods of tillage such as tillage of blood (yunta of cattle, horses, among others) and do not work with the machinery due to the fear that exists among the comuneros to have accidents during work.

Among the most common accidents with agricultural machinery are the overturning on the tractor (it should be noted that no studies have been made to tabulate the accident rate in the MAG), in the area of the motocultores the most common accidents are the following:

- Crank knock of the tractor to the operator.

- Blows, bruises and entrapment of the operator due to the runaway of the tiller (inability to maneuver the device), this occurs for two fundamental reasons: the first is that the tiller to break the ground rested only work in first and second gear if mistakenly engages an upper gear runs rampaging the operator in any direction, the second reason is that after approximately 2 hours of work there is a discontinuity in the process of transmission of movement and the walking tractor literally starts jumping for no apparent reason, initially a thermal fault was thought and the problem came from the combustion engine since the problem started with an apparent overload of the engine and it started to give off blackish 
smoke, but then it was found that the effect was in the transmission system and the shocks occurred in this area, if the operator was working in the time range described (after two hours) there was an enormous probability that it would be dragged or lifted by the motocultor, dragging the operator inside and the most dangerous: falling and being caught between the blades of the rotavator, the exposed stage took the life of a person in the community of Achupallas, in Chimborazo.

- Wound by pieces of blades on the feet, the tiller presented the disadvantage that in the first hours of work the blades of the milling machine or in English known as "rotavator" broke, these pieces obviously were buried in the ground and being impossible to see with the naked eye, then the operator or another person who walked had the chance to splinter with such sharp pieces.

- Poor posture in the driver's seat generated back pain in a short time, which could eventually be said to generate an occupational disease.

There are few studies related to the subject in question, only reference is made to work accidents in different spectrums of the industry, among the relevant topics investigated and taken as reference is "Incidence of work accidents declared in Ecuador in the period 20112012" [3], there are no specific topics related to the subject dealt with.

The main objectives of this document are to show the design and manufacture of elements that counteract the risks during the days of work with agricultural machinery; implement the elements of protection in the motocultores that are part of the agricultural mechanization centers belonging to the Ministry of Agriculture and Livestock of Ecuador for subsequent studies to quantify the tacit reduction of work-related accidents in the subject.

Being clearly descriptive this document is about directly attacking the problem that in this case is: the direct relationship between the lack of an electric ignition system in the mentioned rototiller and its manual ignition by means of crank generates accidents, these accidents can occur because not having the corresponding expertise is turned on the crank and sometimes the heat engine gives a countermaquinazo which results in a blow to the person who is trying to start the rototiller, another risk is that the person does not have the right knowledge of what your position should be with respect to the rototiller at the moment of ignition, once it begins to overcome the inertia and start working the heat engine the crank can drag the person to the floor hitting it, or alternatively the crank to the person who lit the rototiller; This problem is solved through the implementation of an electrical ignition system to the aforementioned walking tractor.

Another problem that was narrated was the short life of the blades of the milling machine (main organ of tillage of the tiller), the same that when being buried and being the result of a fracture were sharp elements for farmers, the solution was to improve the reliability of 
said elements of tillage through some tests and then the implementation of the technological solution.

The scope of this research is directly reducing accidents in the agricultural sector through the implementation of an electric ignition system and the solution of the problem of low reliability of the blades of the tiller element of the tiller and thus attack two problems directly: improve productivity with the reliability of the milling machine and reduce accidents due to chipping.

\section{Importance of the problem.}

In Ecuador there is a study from the year 2011 onwards since there are no data tabulated before

at that date in the matter of work accidents declared to the IESS [3] (Ecuadorian Institute of Social Security), the ignorance of the incidence rates in the workplace accidents does not allow to contribute with efficient policies in occupational health and safety.

The incidence of occupational accidents within the agricultural machinery is an important aspect to be taken into account in the industry is the fourth group in number of work accidents (TA) behind the manufacturing industry, community and social service and commerce in general ( figure 1), "According to the data of the Agrifood Statistics Yearbook in 2009, both in the agri-food industry and in agriculture, annually more than 30,000 workers are involved in accidents during their workday" the data is from Spain. [4].

Graphic 1. Number of work accidents according to work activity.

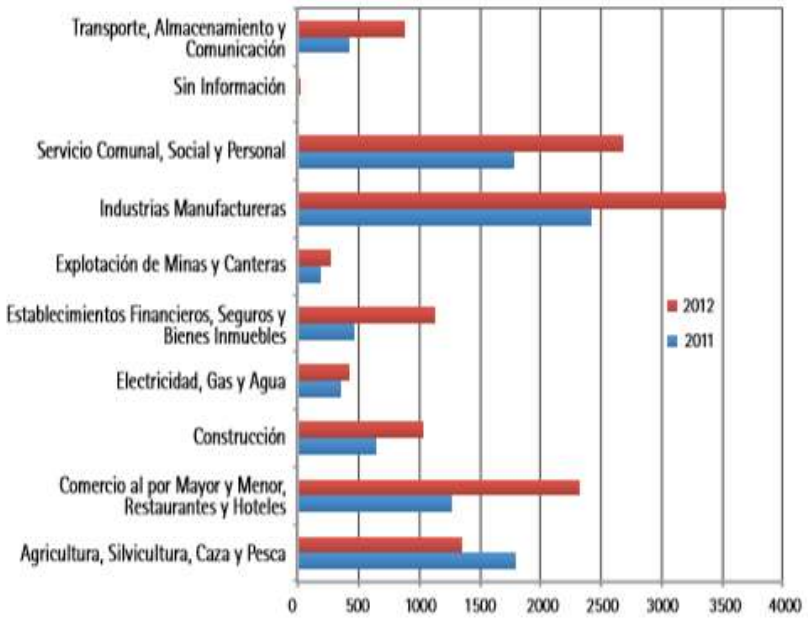

Source: Gómez, A y Suasnavas, P. Ecuador, 2015. 


\section{Methodology.}

Once the main work accidents occurred in the machining centers of the MAG in Chimborazo were determined, which are detailed in the part of the "Introduction" in this document and which are mentioned in a brief manner in this section, being these the following:

\section{Ignition crank knock}

2. Strikes, bruises and entrapment by the tiller

3. Contusions and wounds on the feet by the blades of the rotary milling machine

4. Occupational diseases due to poor posture in the driver's seat of the tiller

To the problems that are going to be treated in this document is to the blows generated by the ignition handle and the bruises and wounds in the feet by the blades of the rotary milling machine, these two themes have been chosen because they are already they have carried out previous studies directed by the author of this research related to the theme of this paper, which are: [5] and [6] respectively.

The theme of the crank and the ignition is crucial since many of the agricultural activities are carried out by both men and women and sometimes horticultural work is carried out to a greater extent by women, therefore, a system should be available. of ignition that is light (in agreement with the standard average force that an average woman can exert), high index of reliability (often the ignition is ignited to the three or four cycles of attempt of ignition) or when the climate is cold it is likely to be tried for a long time there are cases of more than one hour, this generates waste of time and is generating in farmers the idea that it is an impractical and reliable system for their activities, should be the ignition system easy to maneuver: with the current system of crank some steps have to be carried out for the ignition of the automotive system that is purely mechanical, first it has to turn the accelerator knob of the tiller (figure 2), second the fuel valve must be calibrated, third the front support of the tiller must be lowered to stabilize it and fourth the crank base must be inserted in the notch and finally it has to be turned to a torque and a high effort speed to overcome the inertia of the rototiller and to turn it on. 
Graphic 2. Study walking tractor

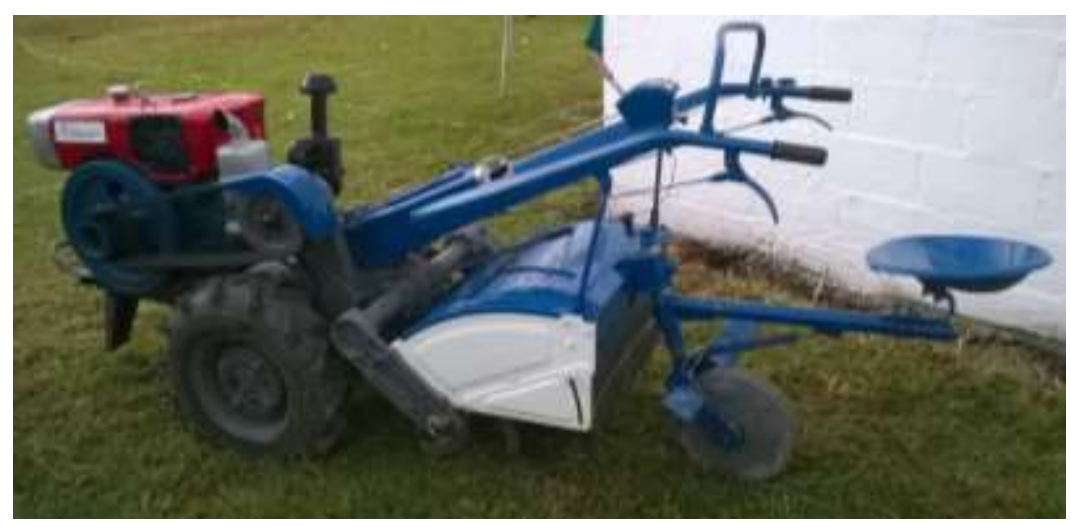

Source: Author y author. Ecuador. 2018,

The methodology that was carried out was to observe the different positions that the farmer takes to light the rototiller and which one generates a greater risk at the moment of lighting, it is probable that a counter-machining occurs and the direction of rotation of the motor which will generate a severe concussion to the person (there is a serious case of this type that was not recorded as a Work Accident), there may be a second scenario where the base of the crank has not been well placed in the notch At the beginning of the movement, the person may lose their balance and hit both the torso and the hands against the rototiller. These injuries are not reported because, according to farmers' criteria, this incident is not important.

To solve the problem has been proposed and carried out the total suppression of the old system of ignition by crank and replaced by an electric ignition system that is very common with the ignition system of a conventional car, ie consists of the following elements in its ignition system: battery or accumulator, connection cables, switch or switch and starter engine.

The inertia flywheel of the tiller was machined so that on its periphery is placed a toothed crown that is in accordance with the bendix (cogwheel connection with the flywheel) of the starter (that the teeth of both the ring gear as of the starter they can mesh with each other without difficulty, which can not be too loose or too tight), as can be seen in figure 3 , then the selection of the ideal starter for the proposed equipment was made if 
Graphic 3. Starter assembly and cogwheel of the flywheel.

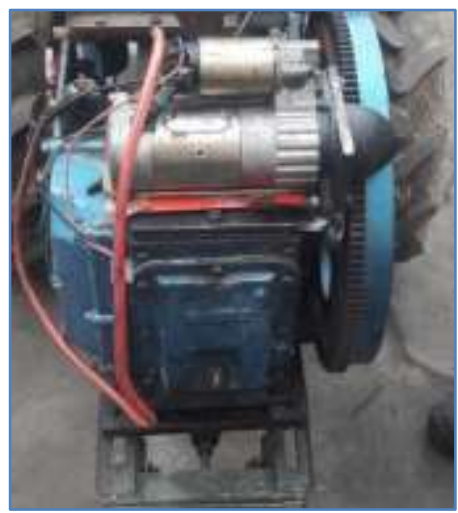

Source: Sánchez. Ecuador 2016.

Some critical aspects are considered at the time of selection such as: environmental conditions, electrical protection index (in this case it does not apply since it is direct current), installation disposition (in this case it is an adaptation and it is probable that it does not have support devices to the original base), nominal power (perhaps the most important since it must move and drag a 16HP heat engine [7]), the work cycles (relatively low since it will only influence the ignition of the tiller), rotation speed (in this aspect it is common for starters that their torque is high but their rotation speed is low), efforts and loads to do the job (the starter will not be subjected to greater efforts), there is to say that both the starter motor and the rototiller are of Chinese origin as shown in figure 4.

Graphic 4. Technical data of the starter motor.

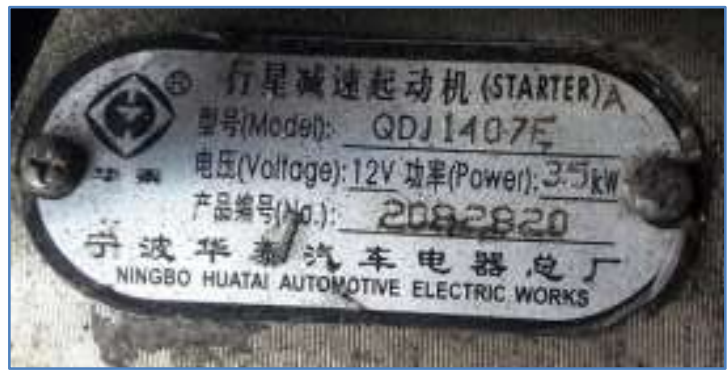

Source: Sánchez. Ecuador.2016. 
When implementing the electric ignition system, it is easy to start the tiller with only a key and when contact is made, the risk of knocks by countermachine and by imbalance of the operator is tangibly reduced.

As mentioned in previous lines, another of the most pressing problems is the breaking of the blades, this problem occurs because the Chinese walking tractor was designed exclusively to till the soil destined for rice cultivation in its country of origin and therefore the benefits are different, the average hardness of the soil is totally different and the working conditions are different: while in Ecuador it has been tried to use the tiller to break the firm soil and more or less humid the other side of the coin is in China where these machines are used to prepare the soil with a view to planting rice. The farming organ with which the producer exports is the classic "rotavator" or known in Spanish as a floor milling machine or simply a milling machine, you can see its appearance in figure 5.

Graphic 5. Rotavator with blades

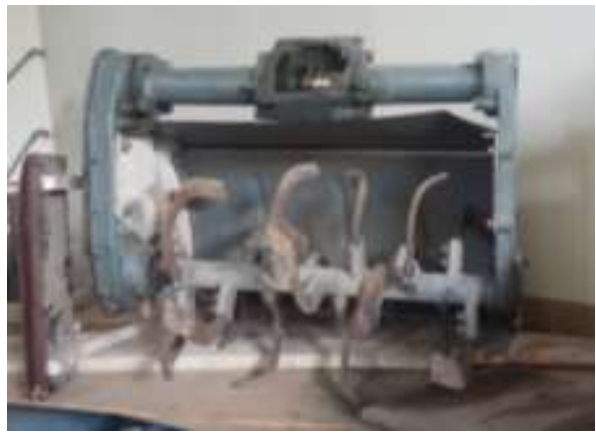

Source: Autor y autor. Ecuador.2018.

When the blades are designed to beat the soil in a mixture with a humidity of $100 \%$, the design considerations are different to the conditions of tillage in Ecuador, it was designed with materials and geometry according to its original requirement, that is why the blades They have a very low reliability index (FI) in other working conditions, close to 0.5 in a work day.

"The main problems are in the geometry and the materials used" [8], in terms of geometry it could be said that the fastening holes become stress concentrators, see graph 6 .

Graphic 6. Stress concentrators in blades.

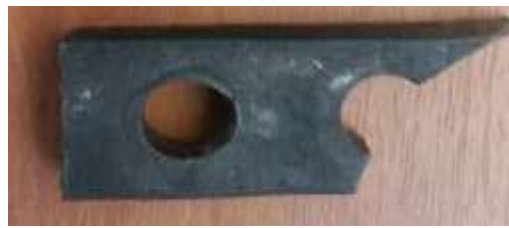

Fuente: Castillo-Bravo.Ecuador.2017. 
After fracturing the blades of the milling machine, the residues are in two parts, the first one is trapped in the milling box between two bolts and the other part remains on the ground generating two imminent risks. The first is the danger of cutting. sharp and sharp edges remain as can be seen in figure 7 .

Graphic 7. Remains of an underground blade.

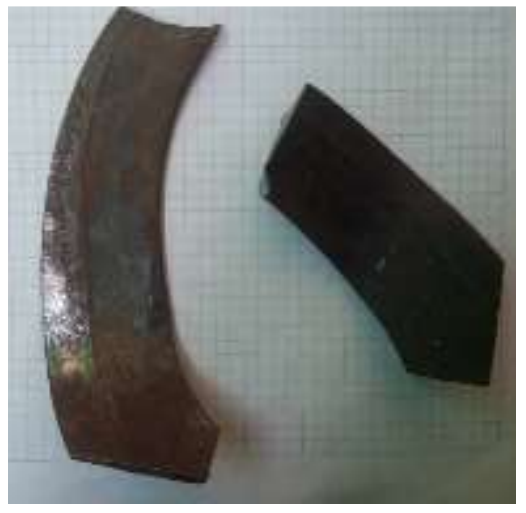

Fuente: Castillo-Bravo. Ecuador.2017.

The second danger is that in a next pass of the machine for the place where the remains of the blades are, it can hit the milling machine and generate more ruptures and these remains can be fired towards the farmer.

The solution that was reached after performing both destructive and non-destructive tests (hardness of the material, metallography, ultrasound, penetrating inks, simulation in CAD-CAE software) was to add material to the critical area and was simulated in the software to know how was their behavior, it was found that with the reinforcement by means of material would not suffer, said procedure consists of two parts: a) place a piece of commercial steel rod construction of a quarter inch in diameter convex of the blade and b) then fill it with weld bead with electrode 6011, this procedure was chosen since it was worked in the construction of another blade in an artisanal way but the cost benefit was low, then the exposed solution was the most viable from the point from a technological and economic point of view, both points were very important since welding is a technology that can be used in the middle and in terms of torque, you could use the same blades economically and then with a reasonable investment reach a good cost-benefit balance, you can see the new blades with the addition of material in graph 10. 
Graphic 10. Added blades material.

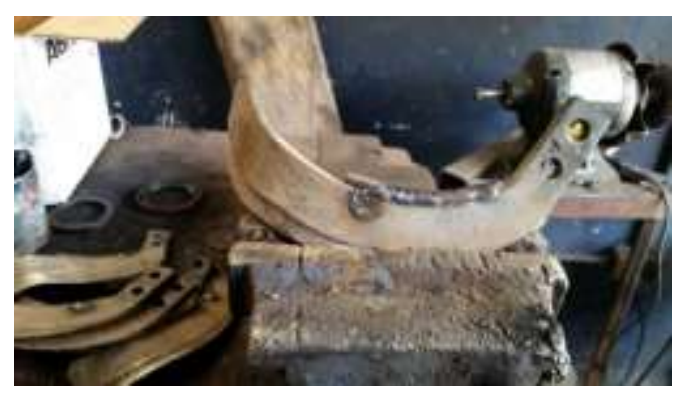

Fuente: Castillo-Bravo.Ecuador.2017.

\section{Results.}

In the first part of this section (Results of the implementation of the Electrical System) it is important to note that consulting various sources to verify the power range of the starter motor for the tiller system has found a work that shows table 1 [9] with the powers required for the starter motor in relation to the size and tonnage of the vehicle to be moved.

Table 1. Common ranges of starting motor power.

\begin{tabular}{ccc}
\hline Vehicle Kind & Potency $(\mathbf{C V})$ & Potency $(\mathbf{k W})$ \\
\hline Light Vehicle & 0,5 to 1 & 0,4 to 0,8 \\
Middle Vehicle & 1 to 3 & 0,8 to 2,2 \\
Heavy Vehicle & 3 to 6 & 2,2 to 5 \\
\hline
\end{tabular}

Source: UTE, Ecuador.2012.

A starter has been selected after the following deliberations: environmental conditions, protection index, installation arrangement, nominal power, work cycles, rotation speed, efforts required to expire; a starter motor of $3.5 \mathrm{~kW}$ (figure 6) equivalent to approximately 4.7HP, it should be noted that said engine was selected in accordance with the theory that indicates that the minimum power of a starter is equal to the sum of the power to start the thermal engine plus the power consumed by the starter, although this data is important is not also commercial items that are in stock, initially selected a starter with less power and weight one of approximately $3 \mathrm{HP}$ but its teeth were incompatible with the cogwheel of the 
flywheel so that the engine of $4.7 \mathrm{HP}$ was finally selected since its bendix fitted perfectly with the gear described.

The second part of this section shows the results of the study of the unreliability of the blades when working in Ecuadorian soil, although in the hardness test the material had a value within the range to be considered "agricultural grade" (45HRC-55HRC), however, the geometry did not help as mentioned in the previous section, the specific resistance of the soil was selected from the tables of the ASABE (American Society of Agronomists and Biologists) [4] as can be seen in the table 2 .

Table 2. Specific soil resistance

\begin{tabular}{cl}
\hline Light Floor & $20-30 \mathrm{kPa}$ \\
\hline Middle Floor & $30-50 \mathrm{kPa}$ \\
Heavy Floor & $50-80 \mathrm{kPa}$ \\
\hline
\end{tabular}

Source: Ortiz-Cañavate. España. 2012

With the original blades of the tiller, a deformation of $1.9 \mathrm{~mm}$ is presented in the software simulation, which, extending the stress towards the stress concentrators (fixing holes), generates the fracture, as can be seen in figure 11 .

Gráfico 11. Simulation of the blade in normal conditions (without adding material).

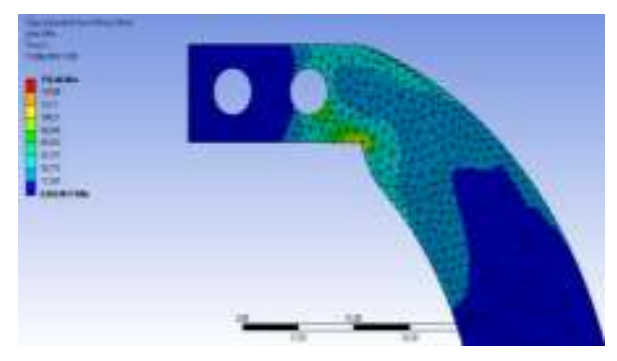

Source: Castillo-Bravo.Ecuador.2017.

Finally, after adding material to the study blade as indicated in the methods section, the value of the deformation in the most severe condition (heavy soil) is $0.25 \mathrm{~mm}$; with which it can be shown that the solution was efficient, adding to that already in the field there were no problems and with this it was evidenced that the new reliability index was 1 . 


\section{Discussion.}

The electric start system has been implemented in the tiller with which work accidents in the field have been completely reduced, no type of accidents or incidents of any kind have been registered in the workshops of the machining centers. it can be asserted that the implementation has been effective.

The solution of the addition of material in the blades of the rotavator has been implemented and in the field tests carried out, no breakage has been determined so that it can be asserted that the solution was also effective, this implies that the risk of suffering injuries for the pieces of buried blades was eliminated.

It could be described as satisfactory results in terms of the two cases studied, the theoretical consequences would result in the blades of the treadmills of the model studied for import or prior to use in the country should have a greater cross section in its convex part , it is recommended for economy to add material following the described process: add a piece of commercial metal rod and then coat it with a common weld bead; importers or marketers of the machine are encouraged to implement the electric ignition system.

There are no works related to the subject proposed specifically in agricultural machinery so they can not be compared or contrasted. There are no works related to the subject proposed specifically in agricultural machinery so they can not be compared or contrasted. It is indicated in the previous section, the number of tests that were carried out to validate the solutions was one English week with 8 test hours each and one half-day rested for an average of two hours. The limitations of the study are the following: there are many other problems in the treadmill that have only been named in this treaty but also require a solution, the authors do not have a model of the tiller to be able to make the respective tests, there are no statistics of the subject of the study treated.

It was tried to give the two best solutions to the main problems of the described machine but in the solution of the implementation of the electrical system another problem arose: the center of gravity of the tiller moved so it tries to rotate forward generating in the instability driver when maneuvering.

The most relevant disadvantages at the time of giving the solutions were generated in the electrical system and were the following: get commercial items for the adaptation of parts and pieces as many parts that were used in the work were old machines that spare parts are not available in stock.

The results of the present study are very valid, and clearly applicable since the respective studies were done for the two cases, no statistics have been applied since there are no data in the subject of study and the present writing is the solution to two specific cases of study. 
This work is important because the farmers do not use the rototiller because their blades break in the first working session, with the described solution in addition to being economical it is practical and they will be able to use the equipment without any doubt or danger, regarding the system Electricity is required to work a little more in the mass transfer of the system and in the commercialization of parts.

\section{Conclusiones.}

- The solution of the addition of material to the blades of the tiller is effective since there was no break in the practices, it is recommended to make an analysis of the blades in penetrating inks or magnetic particles after a month of work.

- The solution for the implementation of the electric ignition system is effective, since the risks of knocks and bruises are completely eliminated, it is recommended to make a dynamic analysis of the tiller as it varies the center of mass and is generated in problems of maneuverability of the walking tractor

- There are no data on accidents at work or the incidence of them in the area of agricultural machinery and / or related fields except for a referenced work done in the years 2011 and 2012, and without it can not be compared with global data and Latin Americans related to the issue so important to make decisions at the governmental level to reduce accidents at work.

- There is not enough stock of implements to carry out the assembly of the ignition system so that it could not be done to the entire trellis plant in Ecuador.

\section{Referencias bibliográficas.}

https://www.eltelegrafo.com.ec/noticias/regional/1/dos-mil-agricultores-se-benefician-delcentro-agricola-mecanizado. [1]

https://www.agricultura.gob.ec/los-centros-de-servicios-mecanizados-transforman-laagricultura/.[2].

Gomez-García, A. (2015). Incidencia de Accidentes de Trabajo reportados en Ecuador en el período 2011-2012. Scielo.Ciencia y Trabajo. Vol 17.N52. pag 4. scielo.conicyt.cl/scielo.php?script=sci_arttext\&pid=S0718-24492015000100010. [3].

Ortiz-Cañavate.(2012). Las Máquinas Agrícolas y su Aplicación. Madrid, España: Ediciones Mundi-Prensa. [4].

Sánchez,J. (2016). Diseño e Implementación de un Sistema de arranque eléctrico para un motocultor modelo YTO DF 151 del MAGAP de la provincia de Chimborazo". Recuperado de http:// http://dspace.espoch.edu.ec/handle/123456789/6260 .[5]. 
Aulla, A, Morejón, H. (2016). Estudio de los factores que inciden en la baja fiabilidad del elemento de labranza de un motocultor YTO DF 151. Recuperado de http://dspace.espoch.edu.ec/bitstream/123456789/5630/1/65T00188.pdf .[6]

YTO. (2000). Manual de usuario del motocultor YTO df 151. China.[7].

Castillo.M,Bravo, D. (2017).“Diseño y construcción de una máquina de desgaste acelerado para homologación de maquinaria agrícola en motocultores para suelos típicos de la región centro del Ecuador: caso de estudio aspas del motocultor YTO DF-15". Recuperado de http:// http://bibdigital.epn.edu.ec/handle/15000/17119. [8].

UTE. 2012. Curso de Electricidad del Automovil. Estudio del Motor de Arranque. [En línea] 2012. [Citado el: 26 de 01 de 2017.] http://www.stodomingo.ute.edu.ec/content/101688-153-20-2-6-

17/Curso\%20de\%20electricidad\%20del\%20automovil\%20\%20Estudio\%20del\%20Motor\%20de\%20arranque.pdf [9] 


\section{Para citar el artículo indexado.}

Castillo E., Bravo V., Abarca E., Sánchez E. \& Montúfar P. . (2018). Design and manufacture of protective elements to prevent accidents in the agricultural machinery of Ecuador, two cases of study in automotive elements. Revista electrónica Ciencia Digital 2(3), 193-208. Recuperado

http://cienciadigital.org/revistacienciadigital2/index.php/CienciaDigital/article/view/146/13 $\underline{1}$

\section{LCiencia}

El artículo que se publica es de exclusiva responsabilidad de los autores y no necesariamente reflejan el pensamiento de la Revista Ciencia Digital.

El articulo queda en propiedad de la revista y, por tanto, su publicación parcial y/o total en otro medio tiene que ser autorizado por el director de la Revista Ciencia Digital.
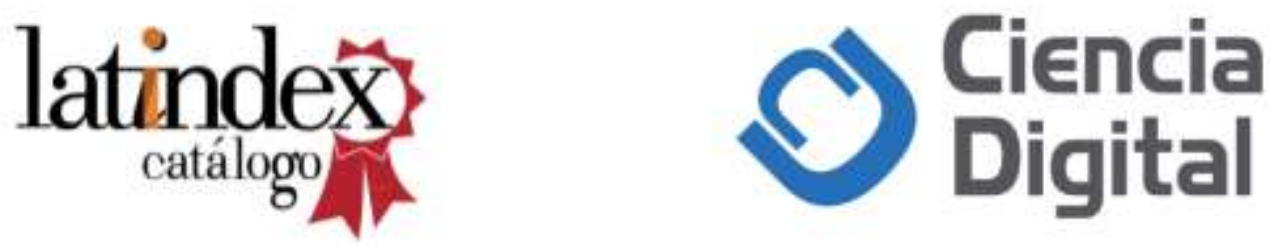